\title{
Factors Associated with Spa Tourists' Satisfaction
}

\author{
Rosa Anaya-Aguilar, German Gemar*(D) and Carmen Anaya-Aguilar \\ Department of Economics and Business Administration, University of Malaga, Campus El Ejido, s/n, \\ 29071 Malaga, Spain; ranaya@uma.es (R.A.-A.); canaya@uma.es (C.A.-A.) \\ * Correspondence: ggemar@uma.es
}

check for

updates

Citation: Anaya-Aguilar, R.; Gemar, G.; Anaya-Aguilar, C. Factors Associated with Spa Tourists' Satisfaction. Mathematics 2021, 9, 332. https://doi.org/10.3390/math9040 332

Academic Editor: José Antonio Filipe Received: 9 January 2021

Accepted: 3 February 2021

Published: 7 February 2021

Publisher's Note: MDPI stays neutral with regard to jurisdictional claims in published maps and institutional affiliations.

\begin{abstract}
Most spas are surrounded by beautiful natural environments, so these facilities contribute to sustainable economic development and their guests are national and local tourists with a high average stay. This study has the objective of analyzing the factors associated with the level of satisfaction and the profile of spa tourists in Andalusia, southern Spain. The methodology used was a quantitative study based on a stratified cross-sectional survey. Each stratum was a spa, with a population of 53,231 users per year, whose final sample included 725 users. The results found were that the profile of Andalusian spa tourists is predominantly female, over 56 years old, and retired with average incomes below one thousand euros. The level of satisfaction of its users is above the average in the factors of accommodation, restaurants, spa, and public roads and natural environment and most of these clients would recommend it to others [92.4\%] and express the intention to return [63.6\%] which indicates that Andalusian spas show a very high level of customer loyalty. The study has the limitation of being cross-sectional quantitative research carried out in Andalusia that could be complemented in future research with a qualitative study with experts. The research presents contributions for companies since they could develop strategies to attract users with younger profiles with activities, prices, or spaces that are more appropriate to their needs and seek the conditions to increase the satisfaction of these segments. The study is original since this research is a quantitative study that shows the real profile of the Andalusian spa tourist and their high level of satisfaction with the spa and their loyalty. The surveys were conducted at each spa by a face-to-face researcher with a response rate of $98 \%$.
\end{abstract}

Keywords: spa; satisfaction; tourism; health; Spain; survey

\section{Introduction}

Thermal springs have long attracted flows of people primarily seeking to improve their health [1,2]. These mineral waters' benefits and properties have been combined with a new understanding of health tourism that requires higher-quality specialized offers that meet increasingly demanding consumers' needs [3-6].

Some authors confirm that tourism experiences connected to water correlate positively with the perception of the quality of life, satisfaction, and loyalty of people both towards the experience and towards the destination [7].

Internationally, according to the Global Wellness Institute [8], the hot springs market is an important business segment of the wellness tourism industry. More specifically, the spa sector in 2017 included more than 149,000 facilities, with $\$ 93.6$ billion in revenue, and 2.5 million workers. The spa sector grew 9.9\% annually between 2015 and 2017, and the forecast for 2022 is that earnings will reach $\$ 128$ billion [8,9]. In addition, international wellness tourists spend an average of $\$ 1528$ per trip, 53\% more than the typical international tourist. Likewise, national wellness tourists spend $\$ 609$ per trip, $178 \%$ more than the average national tourist [10]. In addition, health tourism is an expanding phenomenon [11] and one of the fastest growing forms of tourism at the moment [12] although according to the UNWTO (United Nations World Tourism Organization), due to the Covid-19 pandemic, tourism will take two or three years to recover those levels [13]. 
In this context, visits to thermal spring facilities and other derivatives such as spas are an increasingly common practice and there are studies that indicate that spa tourists seek a better quality of life and flee from mass tourism [14].

In the approach to the research topic, it was found that Andalusia had thermal stations that, precisely due to the characteristics of its waters in terms of temperature and minerals, act as a focus of attraction for tourists [15] and the tourism of spas in Andalusia was studied, which from the tourist point of view, is not as studied as sun and beach tourism.

Thus, the objective of this research was to analyze the factors associated with the level of satisfaction and the profile of spa tourists in Andalusia, southern Spain based on a stratified cross-sectional survey in which each stratum was a specific spa. The estimated study population was 53,231 spa users per year, and the final sample included 725 respondents.

This paper is structured as follows. Section 2 reviews the relevant literature. Section 3 covers the methodology, data collection procedures, and questionnaire reliability. The results, discussion, and conclusions are presented in Section 4, Section 5, and Section 6, respectively.

\section{Literature Review}

The global boom in health tourism [8] has led destinations and companies to specialize in health and wellness tourism as part of their corporate strategy. For some destinations, health tourism can be a way to combat seasonality and diversify coastal tourism [16]. Tourism has also contributed to the sustainable development of rural destinations.

Academic research has studied the factors that attract spa tourists. An example of this is the market segmentation study carried out with a survey of 2050 spa tourists in Poland [17] which has shown that demand is significantly dependent on consumers' choice of particular forms of therapeutic spa treatments based on multiple factors such as age, education, size of tour groups, past spa experiences, type of guest, length of stay, and expected benefits [18]. People use relaxation and tourism to enhance and manage their physical wellbeing in accordance with new concepts and dimensions of health, which the market has taken advantage of, significantly diversifying the offers and incorporating a new range of services. These take a holistic approach to the body that seek to take into account the quite different motivations of individual consumers $[19,20]$.

Other studies have revealed that the feeling of enjoyment and better health is intensified by the wellbeing provided by the environment, the interaction with other users, and the staff who attend them [21].

In addition, other investigations add that in addition to the therapeutic qualities of the waters, the social aspects and the desire to know the geological elements of these places act as an attraction factor [22].

Spa companies offering a wide range of services are looking for new customer value propositions to attract new market segments as, until now, spas have tended to focus on their natural resources [23].

A study of spa tourism in Thailand found that the quality and satisfaction of tourists act as forces that promote loyalty to the destination [24].

Other studies have also shown that satisfaction is positively correlated with repeat purchases of services, loyalty, and intentions to recommend products to others [25].

Some research has concentrated on identifying which key destination attributes contribute to specific tourists' overall satisfaction, such as individuals who visit Mallorca in the low season, and analyzing these tourists' loyalty to the relevant destinations [26,27]. The existing literature focuses only on controllable attributes, so uncontrollable factors such as climate or landscape have not been taken into account because they are difficult to change when tourists are dissatisfied [28]. Conclusions drawn from these studies include that the attractions offered by destinations, facilities, activities, and services have a great impact on visitors' intention to return and recommend [26-28].

Tourists who repeatedly visit a destination are overall more satisfied than those who come for the first time. Younger tourists, in turn, are less satisfied than older tourists. Researchers have also concluded that destination recommendation's impact is more im- 
portant than intention to return since the latter is subject to multiple tourist motivations [26,27]. Many studies further link customer satisfaction with tourism establishments' location [29-32], so location is associated with these companies' survival [33-35].

The literature connecting tourist satisfaction and quality of service in tourism destinations is extensive [36-39]. For instance, customers can be satisfied with some services and not with others [40]. Other authors have focused on satisfaction as a construct that depends on perceived quality [18]. Given these findings, the present study's aims included verifying thermal spa tourism's contribution to the surrounding destinations' overall perceived quality as spa facilities can be important tourist attractions.

Relevant research has been carried out on quality in sun and sand tourism destinations specifically in the Costa del Sol [41]. The cited author designed a methodology and system of quality indicators that were then applied to three mature sun and beach tourism destinations-Torremolinos, Benalmádena, and Marbella. Otero Cordones [41] adapted previous methodologies used in studies evaluating the quality of services in this particular context. The cited research's cluster analysis revealed differences between tourists in terms of the weight that each tourist assigns to the factors under study, Thus, their investigations revealed that the factors with the highest average satisfaction in sun and beach tourism were accommodation and restaurants, while factors such as public infrastructure had a lower value than the average.

Studies have also used the chi-square automatic interaction detection [CHAID] algorithm to conduct market segmentation research on tourists. The results indicate that the most significant variable explaining intention to return is the number of previous visits to the destination in question, as a direct relationship exists between the two variables $[17,42-45]$. When tourists visit a destination for the first time, the variable that most influences their intention to return is their weighted overall satisfaction. If the tourists have previously visited the destination, CHAID analysis highlights place of stay as the variable that most strongly affects their intention to return.

Researchers have also compared the SERVQUAL and SERVPERF scales' ability to measure the perceived quality of thermal spas [46]. The cited study was based on surveys of 12 thermal spring facilities in the Autonomous Community of Galicia. Some authors [46] found that most clients of these thermal spas are Spanish and, more specifically, Galician. In addition, the typical clients are individuals over 65 years old and married or with a life partner, without any formal education or with a primary education, as well as having a low income [i.e., an average family unit monthly income of less than 600 euros]. The results clearly confirm quality of service and customer satisfaction's influence on behavioral intentions in the tourism industry.

A market study conducted by Nextel in retail agencies throughout Spain found that thermal spa tourism has an extremely wide range of possible consumers [47]. To commercialize their products correctly, spas must take into account four very specific types of clients. The first segment is young weekend clients without specific needs who seek to enjoy a pleasant, relaxed weekend and who benefit from anti-stress treatments that are more fun than therapeutic. These consumers consider price decisive in their choice of destinations or products [47].

The second segment is clients between 35 and 55 years old with specific needs regarding therapeutic treatments, for whom price is a secondary factor compared to spas' specialization in specific medical conditions or facilities. The third segment is clients 55 years and older, who are also interested in specific establishments in which their ailments can be treated but whose choices are strongly affected by price. These consumers do not pay excessive attention to other factors such as establishments' category and additional services [47].

The last segment is company clients looking for new alternatives to traditional hotels in which to hold meetings involving internal departments, which can be given as gifts to their clients or distributors, and which offer the added value of thermal spa treatments. Price is not a decisive factor overall, although these consumers' selections must fit an 
existing advertising and/or promotion budget [48]. Basically, this final segment prefers 2- to 4-day stays with extremely simple treatments. Other studies focused especially on thermal spa therapies are in agreement with the cited researchers that this type of tourism mainly attracts older people [49].

The profile of the visitor to Spanish spas is mostly women over 60 years of age and $98 \%$ are of national origin. Further, $58 \%$ stay more than 8 days, 32\% stay between 3 days and a week and respond to an age range of 30 to 45 years. Additionally, $40 \%$ of users receive an average of between 3 and 5 treatments, the most demanded being water services (68\%), followed by manual techniques ( $12.7 \%$ of cases). The average cost of the client ranges between 251 and 500 euros (National Observatory of Thermalism). Health tourism in Andalusia is characterized by a high presence of national tourists (78.6\% in 2016) of which $33.3 \%$ are from Andalusia itself, a greater presence of women (54\%) than men (46\%) [50].

\section{Materials and Methods}

\subsection{Data Collection Procedures}

Scientific research can follow two paths: the quantitative approach and the qualitative approach, both being equally valid given that each of these approaches has its own method. Each one establishes different procedures to generate observations, record them, analyze them, and apply the results according to their scope [51].

In market studies [52], both qualitative techniques (Delphi, expert panels, etc.) and quantitative techniques are commonly used, both descriptive or descriptive-analytical cross-sectional studies (as in this case), as well as essay or experiment type studies, or follow-up studies.

The following steps were taken to ensure an appropriate, adequate sample (see Table 1). The sample was designed based on information gathered from external sources, in particular, a telephone and/or email survey of individuals responsible for managing spas. The relevant data were used to calculate the number of users per year per spa, as well as their distribution by age groups and length of stay. The overall population size was estimated at 53,231 users per year with an age equal to or greater than 15 years old. These individuals were thus defined as this study's primary subjects.

Table 1. Distribution of users according to spa $(n=725)$.

\begin{tabular}{ccccccc}
\hline & \multicolumn{2}{c}{ Sample } & \multicolumn{2}{c}{ Population $^{\mathbf{b}}$} & \multicolumn{2}{c}{ Elevation Coefficient ${ }^{\mathbf{c}}$} \\
\hline Spa $^{\mathbf{a}}$ & $\mathbf{n}$ & $\mathbf{( \% )}$ & $\mathbf{N}$ & $\mathbf{( \% )}$ & $\mathbf{N}^{\mathbf{d}}$ & $\mathbf{N}^{\mathbf{e}}$ \\
\hline 1 & 62 & $(8.6)$ & 3800 & $(7.2)$ & 0.844 & 62 \\
2 & 77 & $(10.6)$ & 2883 & $(5.3)$ & 0.504 & 37 \\
3 & 57 & $(7.9)$ & 2549 & $(4.8)$ & 0.613 & 45 \\
4 & 67 & $(9.2)$ & 3000 & $(5.7)$ & 0.613 & 45 \\
5 & 51 & $(7.0)$ & 3046 & $(5.7)$ & 0.817 & 60 \\
6 & 86 & $(11.9)$ & 1241 & $(2.3)$ & 0.191 & 14 \\
7 & 40 & $(5.5)$ & 2200 & $(4.1)$ & 0.749 & 55 \\
8 & 86 & $(11.9)$ & 11520 & $(21.6)$ & 1.825 & 134 \\
9 & 86 & $(11.9)$ & 6000 & $(11.3)$ & 0.953 & 70 \\
10 & 113 & $(15.6)$ & 17,000 & $(31.8)$ & 2.043 & 150 \\
\hline Total & 725 & $(100)$ & 53,231 & $(100)$ & &
\end{tabular}

a: The name of the spa has been purposely omitted to respect the anonymity of the participating companies.

b: Customers/year aged 15 years or older, estimated from company data, etc. (see Methods). ${ }^{c}$ : The sampling has been stratified (spas) with different probabilities of selection in each spa. d: Result of dividing N/n and multiplying by $725 / 53231$. This mode is used with the SPSS program. e : Result of dividing N/n in each spa. This modality is used with the SUDAAN program.

Stratified sampling was used, with each stratum coinciding with one of the participating spas. The sample size was estimated using Equation (1):

$$
\mathrm{n}_{\mathrm{c}}=\operatorname{Deff} * \mathrm{n},
$$


in which $\mathrm{n}_{\mathrm{c}}$ is the size adjusted to ensure complete sampling (i.e., strata) and Deff is the design's effect or the relationship between the variance under stratified sampling and under simple random sampling. This variance was arbitrarily estimated a priori as 1.5 , which was shown to be an overestimate. Any proportion calculated in this study had to meet the requirements of an accuracy of 5\% and a $95 \%$ confidence level, with the worst possibility considered to be $p=0.5$. This implied that $n=384$ and $n_{c}=576$, which was set as the minimum.

The sample size and/or stratum was the result of a proportional fixation (i.e., the largest spas received more than one visit during the survey). The final result was 725 valid questionnaires, which coincides with some authors' suggestion that sample size [53] be based on 10 subjects per analyzed variable. The sample size's adequacy was thus confirmed since 500 subjects would be a quite good sample size and 1000 or more subjects would be an excellent sample size.

The researchers of this study surveyed users in each spa in Andalusia, defined as a center with waters classified as medicinal mining [15] with prior authorization from those responsible. The same researchers asked the questionnaire questions face to face and asked all users on the days they visited each center, and only three users preferred not to participate. The choice of the tourist in the center was not a selection criterion at the origin.

\subsection{Questionnaire Reliability}

A cross-sectional survey design was followed, and the scale validated by [44] in a study assessing the quality of sun and sand tourism destinations on the Costa del Sol was adopted. The final questionnaire included some slight modifications from that used in the cited research. Once the scale was adapted, a diagnostic test was conducted to check test-retest reproducibility with 30 spa users between 15 and 28 years old, who did not belong to the main sample and who had visited 3 spas in the study. The intraclass correlation coefficient or kappa index was used depending on the type of variable (i.e., quantitative or qualitative), with values given based on Landis and Koch's scale [53].

\section{Results}

Regarding the values obtained for each dimension, the highest average values were given to items assessing accommodations (6.08 \pm 1.15$)$, spas $(6.13 \pm 1.08)$, restaurants $(5.99 \pm 1.29)$, and public roads and urban and natural environments $(5.98 \pm 1.22)$. The general satisfaction dimension stands out with an average of $6.17 \pm 1.06$, and the last item evaluating general satisfaction with quality and/or quality to price ratio also was assigned a high average value of $5.58 \pm 1.29$ (see Table 2).

At the population level, the average age of spa tourists in Andalusia is 56 years \pm 0.8 . Female users are a clear majority (61.8\%). In terms of occupation, two large groups stand out among the tourists that visit Andalusian spas: retirees $(53.1 \% \pm 2.1)$ and employed visitors $[34 \% \pm 2.0]$.

Regarding monthly income, the sample includes three main income brackets. These are, first, those who have an average monthly income of less than 500 euros $(29.8 \% \pm 2.0)$; second, those who earn an average of 501 and 1000 euros per month (33.1\% \pm 2.0$)$; and, third, those who have a monthly average income of between 1001 and 1500 euros $(26.6 \% \pm 1.9)$. Thus, a high percentage of the study population fall inside low income brackets.

Tourists who visit Andalusian spas come mostly from the Autonomous Community of Andalusia $(82.9 \% \pm 1.6)$. Users' provinces include those near the spa resorts such as Malaga (21.9\% \pm 1.7$)$, Jaen $(20.4 \% \pm 1.6)$, and Granada $(18.3 \% \pm 1.6)$. The sample has no foreign users (see Table 3). 
Table 2. Distribution of global assessment items' scores by dimension and general satisfaction among users [number $=725]$.

\begin{tabular}{|c|c|c|c|c|}
\hline Question & $\mathrm{DK}^{\mathrm{N} N \mathrm{~A}^{\mathrm{a}}}$ & & Distribution from 1 to $7(\%)^{d}$ & Mean \pm SD $^{\mathrm{e}}$ \\
\hline & $\mathbf{N}^{\mathbf{b}}$ & \% popl. ${ }^{\mathrm{c}}$ & & \\
\hline \multicolumn{5}{|l|}{ Global assessment by dimension ${ }^{\mathrm{f}}$} \\
\hline Accommodations & $84^{g}$ & 8.9 & $0-1-2-6-16-26-48$ & $6.08 \pm 1.15$ \\
\hline Restaurants & 14 & 1.2 & $1-1-3-8-14-25-47$ & $5.99 \pm 1.29$ \\
\hline Spas & 0 & 0.0 & $1-0-1-6-17-26-49$ & $6.13 \pm 1.08$ \\
\hline Sports facilities & 75 & 12.3 & $33-6-5-4-15-20-16$ & $3.87 \pm 2.38$ \\
\hline Leisure, culture, and shopping & 9 & 0.9 & $10-6-10-13-24-22-14$ & $4.58 \pm 1.82$ \\
\hline Public roads/urban and natural environment & 0 & 0.0 & $0-1-4-7-18-23-47$ & $5.98 \pm 1.22$ \\
\hline Transportation infrastructure and additional services & 3 & 0.4 & $5-3-6-11-20-29-25$ & $5.24 \pm 1.65$ \\
\hline General satisfaction & 0 & 0.0 & $0-1-1-4-17-26-50$ & $6.17 \pm 1.06$ \\
\hline General satisfaction with quality/price ratio & 0 & 0.0 & $1-2-3-8-28-31-27$ & $5.58 \pm 1.29$ \\
\hline
\end{tabular}

${ }^{\mathrm{a}} \mathrm{DK} / \mathrm{NA}=$ "Don't know"/no answer; $\mathrm{b}$ " $\mathrm{n}$ " number of unweighted sample; c.\% pop. = Percentage of population, after weighting population; ${ }^{\mathrm{d}}$ percentage distribution (without decimals for simplification) of categories 1 ("Not at all satisfied"), 2, 3, 4, 5, 6, and 7 ("Very satisfied"), after excluding any DK/NA; note that this is a weighted sample; ${ }^{\mathrm{e}}$ mean $\pm \mathrm{SD}=$ weighted arithmetic mean \pm standard deviation, with all cases having valid values; ${ }^{\mathrm{f}}$ note that these scores correspond to single questions by dimension and that these values are different from the average scores by dimension obtained with the main questionnaire of 52 items; $\mathrm{g}$ different from 725 users because this number comprises those who stay in the homes of family and friends (number $=23)$ or those who do not stay overnight $($ number $=61)$.

Slightly more than half $(51.3 \% \pm 2.2)$ of spa tourists in Andalusia travel as a couple, while $19.7 \% \pm 1.7$ are families. In terms of accommodations, $49.6 \% \pm 1.7$ choose three-star hotels. The highest percentage of overnight stays corresponds to those sponsored by the Institute for the Elderly and Social Services (Imserso) $(48.4 \% \pm 2.1)$, followed by weekend and long weekend tourists $(28.1 \% \pm 2.0)$. The average stay is one week. Close to half $(46.8 \% \pm 2.2)$ of these spa users repeat their visit, while nearly all book their trips without intermediaries and only use the spas' services $(99.1 \% \pm 0.4)$ (see Table 4$)$.

Table 3. Sociodemographic distribution of users (number $=725$ ).

\begin{tabular}{|c|c|c|c|}
\hline & Sample & & Population \\
\hline Variable & $\mathrm{N}^{\mathrm{a}}$ & $(\%)$ & $\% \pm \mathbf{s e}^{\mathbf{b}}$ \\
\hline \multicolumn{4}{|l|}{ Age (years) } \\
\hline $15-35$ & 137 & $(18.9)$ & $18.1 \pm 1.6$ \\
\hline $36-49$ & 116 & $(16.0)$ & $14.6 \pm 1.5$ \\
\hline $50-64$ & 149 & $(20.6)$ & $21.2 \pm 1.8$ \\
\hline $65-88$ & 323 & $(44.6)$ & $46.1 \pm 2.1$ \\
\hline Mean $\pm s d / s^{c}$ & $55.2 \pm 18.3$ & $56.0 \pm 0.8$ & \\
\hline \multicolumn{4}{|l|}{ Gender } \\
\hline Male & 286 & $(39.4)$ & $38.2 \pm 2.1$ \\
\hline Female & 439 & $(60.6)$ & $61.8 \pm 2.1$ \\
\hline \multicolumn{4}{|l|}{ Occupation } \\
\hline Employed & 268 & $(37.0)$ & $34.0 \pm 2.0$ \\
\hline Housewife & 45 & $(6.2)$ & $5.8 \pm 1.0$ \\
\hline Student $(n=48)$ or unemployed $(n=3)$ & 51 & $(7.0)$ & $7.0 \pm 1.1$ \\
\hline Retired & 361 & $(49.8)$ & $53.1 \pm 2.1$ \\
\hline \multicolumn{4}{|l|}{ Monthly income (euros) } \\
\hline$<500$ & 207 & $(28.6)$ & $29.8 \pm 2.0$ \\
\hline 501-1000 & 229 & (31.6) & $33.1 \pm 2.0$ \\
\hline 1001-1500 & 194 & $(26.8)$ & $26.6 \pm 1.9$ \\
\hline $1501-2000$ & 77 & (10.6) & $8.6 \pm 1.1$ \\
\hline $2001-2500$ & 11 & $(1.5)$ & $1.0 \pm 0.3$ \\
\hline $2501-3000$ & 4 & $(0.6)$ & $0.7 \pm 0.4$ \\
\hline$>3000$ & 3 & $(0.4)$ & $0.2 \pm 0.1$ \\
\hline
\end{tabular}


Table 3. Cont.

\begin{tabular}{|c|c|c|c|}
\hline & Sampl & & Population \\
\hline Variable & $\mathrm{N}^{\mathrm{a}}$ & $(\%)$ & $\% \pm \mathbf{s e}^{\mathbf{b}}$ \\
\hline \multicolumn{4}{|l|}{ Region of origin $^{c}$} \\
\hline Andalusia (total) & 596 & $(82.2)$ & $82.9 \pm 1.6$ \\
\hline Canary Islands & 2 & $(0.3)$ & $0.1 \pm 0.1$ \\
\hline Cantabria & 1 & $(0.1)$ & $0.0 \pm 0.0$ \\
\hline Castilla Leon & 2 & $(0.3)$ & $0.1 \pm 0.1$ \\
\hline Castilla Mancha & 13 & (1.8) & $2.6 \pm 0.8$ \\
\hline Catalonia & 22 & (3.0) & $2.3 \pm 0.5$ \\
\hline Extremadura & 3 & $(0.4)$ & $0.2 \pm 0.1$ \\
\hline La Rioja & 2 & $(0.3)$ & $0.2 \pm 0.1$ \\
\hline Madrid & 55 & (7.6) & $7.9 \pm 1.1$ \\
\hline Murcia & 4 & (0.6) & $1.1 \pm 0.6$ \\
\hline Basque Country & 2 & $(0.3)$ & $0.2 \pm 0.2$ \\
\hline Valencia & 16 & $(2.2)$ & $1.7 \pm 0.5$ \\
\hline Ceuta/Melilla & 7 & (1.0) & $0.5 \pm 0.2$ \\
\hline \multicolumn{4}{|c|}{ Andalusian provinces [percentage of total) } \\
\hline Almeria & 73 & $(10.1)$ & $8.3 \pm 0.8$ \\
\hline Cadiz & 39 & $(5.4)$ & $4.5 \pm 0.8$ \\
\hline Cordoba & 25 & $(3.4)$ & $2.7 \pm 0.6$ \\
\hline Granada & 127 & $(17.5)$ & $18.3 \pm 1.6$ \\
\hline Huelva & 5 & $(0.7)$ & $0.9 \pm 0.5$ \\
\hline Jaen & 104 & $(14.3)$ & $20.4 \pm 1.6$ \\
\hline Malaga & 178 & $(24.6)$ & $21.9 \pm 1.7$ \\
\hline Sevilla & 45 & $(6.2)$ & $5.7 \pm 1.0$ \\
\hline
\end{tabular}

a: Population percentage \pm standard error, taking into account the weight of the sample and stratified sampling (Spas) with SUDAAN. ${ }^{\text {: }}$ The "sd" (standard deviation) has been calculated in the case of the sampling distribution and the "se" (standard error) in the population distribution. ": In the sample, there was no user from abroad or from the Autonomous Communities of Aragon, As-turias, Balearic Islands, Galicia, or Navarra.

Table 4. Description of visits to spas (number $=725$ ).

\begin{tabular}{|c|c|c|c|}
\hline & Sample & & Population \\
\hline Variable & n & $(\%)$ & $\% \pm \mathbf{s e}^{\mathrm{a}}$ \\
\hline \multicolumn{4}{|l|}{ Travel group } \\
\hline Alone & 96 & $(13.2)$ & $12.9 \pm 1.4$ \\
\hline In couple & 366 & $(50.5)$ & $51.3 \pm 2.2$ \\
\hline With friends & 103 & $(14.2)$ & $15.9 \pm 1.6$ \\
\hline In family & 158 & $(21.8)$ & $19.7 \pm 1.7$ \\
\hline Others & 2 & $(0.3)$ & $0.2 \pm 0.1$ \\
\hline \multicolumn{4}{|l|}{ Type of accommodation } \\
\hline No overnight stay & 61 & $(8.4)$ & $5.8 \pm 0.6$ \\
\hline Family/friends' house & 23 & $(3.2)$ & $3.1 \pm 0.7$ \\
\hline Apartment/chalet rental unit & 95 & $(13.1)$ & $7.2 \pm 1.0$ \\
\hline Hostel/pension & 44 & $(6.1)$ & $5.5 \pm 0.9$ \\
\hline 2-star hotel & 126 & $(17.4)$ & $17.4 \pm 1.5$ \\
\hline 3-star hotel & 268 & $(37.0)$ & $49.6 \pm 1.7$ \\
\hline 4-star hotel & 3 & $(0.4)$ & $0.4 \pm 0.3$ \\
\hline Spa & 105 & (14.5) & $11.0 \pm 0.8$ \\
\hline \multicolumn{4}{|l|}{ Overnight stays (this visit) (\%) } \\
\hline $0=$ "come and go" & 61 & $(8.4)$ & $5.8 \pm 0.6$ \\
\hline $1-3=$ "weekends and long weekends" & 174 & $(24.0)$ & $28.1 \pm 2.0$ \\
\hline $4-11=$ "vacation week" & 87 & $(12.0)$ & $12.8 \pm 1.4$ \\
\hline $12=$ "Imserso" & 303 & $(41.8)$ & $48.4 \pm 2.1$ \\
\hline $13-20=$ "private retirees" & 100 & (13.8) & $4.9 \pm 0.6$ \\
\hline Mean \pm sd $/$ se $^{b}$ & $8.4 \pm 5.3$ & $8.0 \pm 0.2$ & \\
\hline \multicolumn{4}{|l|}{ Previous visits in the last 5 years $(\%)$} \\
\hline $0=$ "no previous visit" & 366 & $(50.5)$ & $53.2 \pm 2.2$ \\
\hline$\geq 1=$ "repeat" & 359 & $(49.5)$ & $46.8 \pm 2.2$ \\
\hline Mean \pm sd $/$ se $^{b}$ & $1.52 \pm 2.06$ & $1.32 \pm 0.08$ & \\
\hline \multicolumn{4}{|l|}{ Type of booking } \\
\hline Tourist package (spa, accommodations, and others) & 7 & $(1.0)$ & $0.9 \pm 0.4$ \\
\hline Only spa services & 714 & $(99.0)$ & $99.1 \pm 0.4$ \\
\hline DK/NA & 4 & & \\
\hline
\end{tabular}

a: Population percentage \pm standard error, taking into account the weight of the sample and stratified sampling (Spas) with SUDAAN. ' : "sd" (standard deviation) has been calculated in the case of the sampling distribution and the "se" (standard error) in the population distribution. A full $92.4 \% \pm 1.1$ of the respondents reported that they intended to recommend the spas, while only $2.0 \% \pm 0.6$ had no intention of recommending them. Nearly two-thirds $(63.6 \% \pm 2.0)$ of the tourists surveyed said they intended to return the following year, and just $1.6 \% \pm 0.5$ had no intention of ever returning (see Table 5). 
Table 5. Distribution of users' future intentions (number $=725)^{a}$.

\begin{tabular}{cccc}
\hline & Sample & & Population \\
\hline Variable & $\mathbf{n}$ & $\mathbf{( \% )}$ & $\mathbf{\%} \pm \mathbf{s e} \mathbf{b}^{\mathbf{0}}$ \\
\hline Yes & & & \\
No & 665 & $(91.7)$ & $92.4 \pm 1.1$ \\
Does not know & 17 & $(2.3)$ & $2.0 \pm 0.6$ \\
Intention to recommend & 43 & $(5.9)$ & $5.6 \pm 1.0$ \\
Next year & & & \\
This year & 470 & $(64.8)$ & $63.6 \pm 2.0$ \\
Every year & 96 & $(13.2)$ & $11.0 \pm 1.1$ \\
Does not know & 93 & $(12.8)$ & $16.0 \pm 1.7$ \\
Never & 54 & $(7.4)$ & $7.7 \pm 1.2$ \\
& 12 & $(1.7)$ & $1.6 \pm 0.5$ \\
\hline
\end{tabular}

$\bar{a}$ : Note that no cases exist in which these questions were not answered; ${ }^{\mathrm{b}}$ : Population percentage \pm standard error, taking into account the weight of the sample and stratified sampling (Spas) with SUDAAN.

Significant differences were found between the dimensions for the entire sample $(p<0.001)$. After comparing the 7 dimensions in pairs, 4 non-heterogeneous groups of dimensions were obtained. These are, from lowest to highest mean value: (1) sports facilities; (2) infrastructure, transportation, and other services; (3) leisure, culture, and shopping; and (4) accommodations, restaurants (i.e., meals), spas, and public roads and/or urban and natural environments (see Table 6).

Table 6. Distribution of scores by dimensions and totals for the main questionnaire (52 items) (number $=725$ ).

\begin{tabular}{|c|c|c|c|c|c|}
\hline Questions & Distribution from 1 to $7(\%)^{a}$ & Mean $\pm \mathbf{s d}^{\mathbf{b}}$ & $\mathrm{se}^{\mathrm{c}}$ & $95 \% \mathrm{CI}^{\mathrm{d}}$ & $\begin{array}{c}p \text {-Global } \\
\text { in Pairs }^{\mathrm{e}}\end{array}$ \\
\hline Dimensions & & & & & $p<0.001^{\mathrm{e}}$ \\
\hline Accommodations & $0-0-4-9-36-51$ & $5.89 \pm 0.89$ & 0.04 & $5.81-5.97$ & $\mathrm{z}$ \\
\hline Restaurants (meals) & $0-2-7-9-21-61$ & $5.91 \pm 1.14$ & 0.05 & $5.81-6.01$ & $\mathrm{z}$ \\
\hline Spas & $0-0-3-10-29-58$ & $5.92 \pm 0.84$ & 0.03 & $5.86-5.98$ & $\mathrm{z}$ \\
\hline Sports facilities & $20-14-21-14-16-15$ & $3.85 \pm 1.72$ & 0.06 & $3.73-3.97$ & $\mathrm{w}$ \\
\hline Leisure, culture, and shopping & $6-12-16-25-24-16$ & $4.41 \pm 1.44$ & 0.05 & $4.31-4.51$ & $\mathrm{y}$ \\
\hline Public roads/urban and natural environments & $0-2-3-12-24-59$ & $5.93 \pm 1.00$ & 0.04 & $5.85-6.01$ & $\mathrm{Z}$ \\
\hline Transportation infrastructure and additional services & $5-13-16-35-23-7$ & $4.22 \pm 1.26$ & 0.04 & $4.14-4.30$ & $x$ \\
\hline Total score & $0-1-7-21-45-27$ & $5.38 \pm 0.83$ & 0.04 & $5.30-5.46$ & \\
\hline
\end{tabular}

a Percentage distribution (without decimals for simplification) in 6 categories separated by hyphens, ranging from 1 ("Not at all satisfied") to 7 ("Very satisfied"): $1 \mathrm{a}<2 ; 2 \mathrm{a}<3 ; 3 \mathrm{a}<4 ; 4 \mathrm{a}<5 ; 5 \mathrm{a}<6$; and 6 to 7 ; note that this is a weighted sample; ${ }^{\text {b }}$ Arithmetic mean \pm standard deviation, weighted. ${ }^{c}$ standard error, ponderado y taking into account stratified sampling using SUDAAN software's DESCRIPT procedure; $\mathrm{d} 95 \% \mathrm{CI}=$ confidence interval, calculated as mean $\pm 1.96 \mathrm{x} \mathrm{se} ;{ }^{\mathrm{e}}$ calculated using SUDAAN software's REGRESS procedure; numerical value of $\mathrm{p}$ given; ${ }^{\mathrm{f}}$ multiple pairwise comparisons using SUDAAN software's DESCRIPT procedure; means with different letters ( $\mathrm{w}-\mathrm{z}$ ) are statistically different ( $p<0.05$, after Bonferroni correction for multiple comparisons).

Univariate analysis was conducted using simple linear regression models, and each spa facilities' statistical significance was obtained for the spa dimension. The results indicate that the spas under study are extremely heterogeneous $(p<0.05)$. More specifically, significant differences exist between facilities' visitors for the variables age, occupation, and income. Overall, older people, retirees, and those with incomes of less than or equal to 1000 euros are more satisfied.

In addition, significant results were obtained with reference to family versus other visitors traveling alone, in pairs, and with friends, with tourists who come with their family being less satisfied. Regarding accommodations in 3- and 4-star spa hotels, people staying in more luxurious hotels are more satisfied. The number of overnight stays is also important since satisfaction increases as guests spend more days in the spas (see Table 7). 
Table 7. Univariate association using simple linear regression models ${ }^{\text {a }}$ of spa, sociodemographic, and visitor variables, with scores according to each dimension ${ }^{b}$ and totals obtained from main questionnaire (52 items) (number $\left.=725\right)$.

\begin{tabular}{|c|c|c|c|c|c|c|c|c|}
\hline \multirow{2}{*}{ Variable } & ACC & RES & SPA & SPO & LEI & PUB & INF & Total Score \\
\hline & $\beta \pm$ se & $\beta \pm$ se & $\beta \pm$ se & $\beta \pm$ se & $\beta \pm$ se & $\boldsymbol{\beta} \pm$ se & $\beta \pm$ se & $\beta \pm$ se \\
\hline \multicolumn{9}{|l|}{ Spa (Ref. spa no. 10) } \\
\hline 1 & $0.30 \pm 0.13 *$ & $0.06 \pm 0.20$ & $0.45 \pm 0.13 *$ & $0.60 \pm 0.19 *$ & $-1.90 \pm 0.21 *$ & $0.58 \pm 0.14$ * & $-1.28 \pm 0.19 *$ & $-0.07 \pm 0.14$ \\
\hline 2 & $0.50 \pm 0.12 *$ & $0.60 \pm 0.14 *$ & $0.72 \pm 0.12 *$ & $1.44 \pm 0.17 *$ & $-1.05 \pm 0.20 *$ & $0.52 \pm 0.12 *$ & $-1.95 \pm 0.16^{*}$ & $0.13 \pm 0.12$ \\
\hline 3 & $0.15 \pm 0.14$ & $-0.30 \pm 0.19$ & $0.93 \pm 0.10 *$ & $0.89 \pm 0.18 *$ & $-1.64 \pm 0.19 *$ & $-0.93 \pm 0.19 *$ & $-0.68 \pm 0.19 *$ & $-0.29 \pm 0.11 *$ \\
\hline 4 & $0.61 \pm 0.13 *$ & $0.58 \pm 0.16^{*}$ & $0.78 \pm 0.12 *$ & $0.71 \pm 0.17 *$ & $0.04 \pm 0.16$ & $-0.20 \pm 0.15$ & $-0.15 \pm 0.14$ & $0.33 \pm 0.11^{*}$ \\
\hline 5 & $0.37 \pm 0.11 *$ & $0.59 \pm 0.15 *$ & $0.70 \pm 0.13 *$ & $-0.72 \pm 0.17 *$ & $-2.10 \pm 0.18 *$ & $-0.09 \pm 0.18$ & $-1.75 \pm 0.17 *$ & $-0.33 \pm 0.12 *$ \\
\hline 6 & $-0.52 \pm 0.14 *$ & $-0.54 \pm 0.18 *$ & $-0.47 \pm 0.14 *$ & $-0.35 \pm 0.21$ & $-1.87 \pm 0.18 *$ & $-0.25 \pm 0.14$ & $-1.24 \pm 0.17 *$ & $-0.80 \pm 0.13 *$ \\
\hline 7 & $0.25 \pm 0.09 *$ & $-0.16 \pm 0.26$ & $-0.03 \pm 0.13$ & $-0.60 \pm 0.17 *$ & $-3.45 \pm 0.13 *$ & $0.78 \pm 0.13^{*}$ & $-2.13 \pm 0.12 *$ & $-0.56 \pm 0.13 *$ \\
\hline 8 & $0.25 \pm 0.14$ & $0.61 \pm 0.16^{*}$ & $0.55 \pm 0.12 *$ & $2.77 \pm 0.17 *$ & $-0.81 \pm 0.15 *$ & $0.46 \pm 0.13 *$ & $0.45 \pm 0.14 *$ & $0.42 \pm 0.12 *$ \\
\hline 9 & $0.41 \pm 0.13$ * & $0.52 \pm 0.15 *$ & $0.91 \pm 0.10 *$ & $2.69 \pm 0.17 *$ & $0.36 \pm 0.14 *$ & $0.20 \pm 0.13$ & $-0.33 \pm 0.11$ * & $0.50 \pm 0.10$ * \\
\hline Age (years) & $0.01 \pm 0.00 *$ & $0.01 \pm 0.00 *$ & $0.01 \pm 0.00 *$ & $-0.01 \pm 0.00$ & $0.02 \pm 0.00 *$ & $0.01 \pm 0.00 *$ & $0.01 \pm 0.00 *$ & $0.01 \pm 0.00$ * \\
\hline $\begin{array}{l}\text { Gender: male } \\
\text { (ref. female) }\end{array}$ & $-0.05 \pm 0.09$ & $-0.14 \pm 0.10$ & $-0.08 \pm 0.08$ & $0.00 \pm 0.16$ & $-0.04 \pm 0.12$ & $-0.05 \pm 0.09$ & $0.02 \pm 0.11$ & $-0.06 \pm 0.08$ \\
\hline $\begin{array}{l}\text { Other occupations } \\
\text { (ref. retired) }\end{array}$ & $-0.41 \pm 0.08^{*}$ & $-0.57 \pm 0.10 *$ & $-0.39 \pm 0.07$ * & $0.01 \pm 0.15$ & $-0.85 \pm 0.11$ * & $-0.35 \pm 0.08 *$ & $-0.34 \pm 0.10 *$ & $-0.52 \pm 0.07^{*}$ \\
\hline $\begin{array}{l}\text { euros/month } \\
\text { (ref. 1001) }\end{array}$ & $0.16 \pm 0.10$ & $0.47 \pm 0.15 *$ & $0.21 \pm 0.09 *$ & $0.62 \pm 0.19$ * & $0.12 \pm 0.15$ & $0.05 \pm 0.10$ & $0.18 \pm 0.13$ & $0.25 \pm 0.10 *$ \\
\hline $\begin{array}{l}\text { Origin: Andalusia } \\
\text { (ref. other regions) }\end{array}$ & $0.17 \pm 0.08^{*}$ & $0.10 \pm 0.10$ & $0.06 \pm 0.08$ & $-0.26 \pm 0.15$ & $0.35 \pm 0.12 *$ & $0.07 \pm 0.09$ & $-0.01 \pm 0.11$ & $0.13 \pm 0.07$ \\
\hline \multicolumn{9}{|l|}{$\begin{array}{l}\text { Travel group (ref. } \\
\text { family and others) }\end{array}$} \\
\hline Alone & $0.44 \pm 0.12 *$ & $0.81 \pm 0.17 *$ & $0.56 \pm 0.12$ * & $0.30 \pm 0.28$ & $0.27 \pm 0.20$ & $0.38 \pm 0.14$ * & $0.26 \pm 0.18$ & $0.50 \pm 0.13$ * \\
\hline As a couple & $0.25 \pm 0.11 *$ & $0.62 \pm 0.14 *$ & $0.36 \pm 0.11 *$ & $-0.23 \pm 0.21$ & $0.64 \pm 0.14 *$ & $0.39 \pm 0.13^{*}$ & $0.15 \pm 0.15$ & $0.40 \pm 0.11^{*}$ \\
\hline With friends & $0.16 \pm 0.13$ & $0.56 \pm 0.16^{*}$ & $0.28 \pm 0.12 *$ & $0.02 \pm 0.27$ & $0.80 \pm 0.18^{*}$ & $0.35 \pm 0.14$ * & $0.21 \pm 0.17$ & $0.38 \pm 0.11^{*}$ \\
\hline \multicolumn{9}{|l|}{$\begin{array}{l}\text { Accommodations } \\
\text { (ref. spa) }\end{array}$} \\
\hline $\begin{array}{l}\text { No overnight } \\
\text { stay/family or } \\
\text { friends' home }^{c}\end{array}$ & $-0.05 \pm 0.08$ & $-0.46 \pm 0.18^{*}$ & $-0.03 \pm 0.12$ & $-0.47 \pm 0.21^{*}$ & $-0.17 \pm 0.25$ & $-0.78 \pm 0.16^{*}$ & $-0.20 \pm 0.20$ & $-0.39 \pm 0.11^{*}$ \\
\hline $\begin{array}{l}\text { Apartment/chalet } \\
\text { rental unit }\end{array}$ & $-0.30 \pm 0.13^{*}$ & $-0.14 \pm 0.18$ & $-0.19 \pm 0.14$ & $0.49 \pm 0.28$ & $1.03 \pm 0.24 *$ & $-0.70 \pm 0.19 *$ & $0.59 \pm 0.23 *$ & $-0.08 \pm 0.14$ \\
\hline $\begin{array}{l}\text { Hostel/2-star hotel } \\
\text { 3-/4-star hotel }\end{array}$ & $\begin{array}{c}-0.10 \pm 0.12 \\
0.02 \pm 0.11\end{array}$ & $\begin{array}{c}0.18 \pm 0.17 \\
0.33 \pm 0.15 *\end{array}$ & $\begin{array}{c}-0.08 \pm 0.13 \\
0.07 \pm 0.11\end{array}$ & $\begin{array}{c}-0.50 \pm 0.18^{*} \\
1.00 \pm 0.17^{*}\end{array}$ & $\begin{array}{l}1.18 \pm 0.21 * \\
1.57 \pm 0.18^{*}\end{array}$ & $\begin{array}{l}-0.26 \pm 0.15 \\
-0.11 \pm 0.12\end{array}$ & $\begin{array}{c}0.32 \pm 0.19 \\
1.29 \pm 0.16^{*}\end{array}$ & $\begin{array}{c}0.07 \pm 0.12 \\
0.42 \pm 0.10^{*}\end{array}$ \\
\hline $\begin{array}{c}\text { Number of } \\
\text { overnight stays }\end{array}$ & $0.02 \pm 0.01$ * & $0.04 \pm 0.01$ * & $0.02 \pm 0.01$ * & $-0.02 \pm 0.01$ & $0.08 \pm 0.01 *$ & $0.02 \pm 0.01 *$ & $0.03 \pm 0.01 *$ & $0.04 \pm 0.01$ * \\
\hline $\begin{array}{l}\text { Number of previous } \\
\text { visits in last } 5 \text { years }\end{array}$ & $0.05 \pm 0.02 *$ & $0.01 \pm 0.03$ & $0.02 \pm 0.02$ & $-0.10 \pm 0.04^{*}$ & $-0.04 \pm 0.03$ & $-0.02 \pm 0.02$ & $-0.06 \pm 0.03 *$ & $0.00 \pm 0.02$ \\
\hline
\end{tabular}

${ }^{\mathrm{a}}$ : Models (one for each variable -column 1- and dimension/total satisfaction value) using the REGRESS procedure of SUDAAN (it takes into account stratified and weighted sampling). The coefficients $\beta$ eta \pm standard error are expressed in the Table against the category

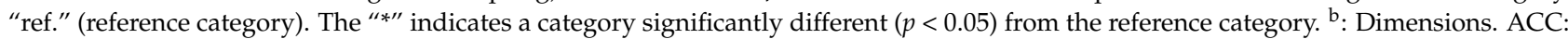
Accommodation, RES: Restoration, SPA: Spa, SPO: Sports facilities, LEI: Leisure/culture/shopping, PUB: Public roads/urban and natural environment, INF: Transport infrastructures and other services. '. The coefficient of this category for the variable "Accommodation" is meaningless, as they were NS/NC values that were substituted for the mean.

Multivariate analysis was conducted using linear regression models of the spa, sociodemographic, and dimension variables. The global scores overall reveal significant differences for four spas, indicating heterogeneity. Occupation is a significant factor, with retirees more satisfied than those in other occupations, and origin is as well, with tourists from Andalusia being more satisfied than those from other autonomous communities. When the scores were examined by dimensions for the age variable, significant values were found for spas and sports. Namely, older tourists reported greater satisfaction with spas, and younger visitors registered lower satisfaction with sports (see Table 8). 
Table 8. Multivariate association using linear regression models a of spa, sociodemographic, and visit variables, with scores by dimension ${ }^{\mathrm{b}}$ and totals obtained from main questionnaire (52 items) (number $\left.=725\right)$.

\begin{tabular}{|c|c|c|c|c|c|c|c|c|}
\hline \multirow{2}{*}{ Predictive Variable } & ACC & RES & SPA & SPO & LEI & PUB & INF & Total Score \\
\hline & $\beta \pm \mathrm{SE}^{\mathrm{c}}$ & $\beta \pm \mathrm{SE}$ & $\beta \pm \mathrm{SE}$ & $\beta \pm \mathrm{SE}$ & $\beta \pm \mathrm{SE}$ & $\beta \pm \mathrm{SE}$ & $\beta \pm \mathrm{SE}$ & $\beta \pm \mathrm{SE}$ \\
\hline \multicolumn{9}{|l|}{ Spa (ref. spa no. 10) } \\
\hline 1 & $0.33 \pm 0.12 *$ & $-0.07 \pm 0.26$ & $0.41 \pm 0.13 *$ & $0.66 \pm 0.18 *$ & $-1.83 \pm 0.21$ * & $0.63 \pm 0.21 *$ & $-1.31 \pm 0.19^{*}$ & $-0.21 \pm 0.19$ \\
\hline 2 & $0.46 \pm 0.12 *$ & $0.66 \pm 0.18^{*}$ & $0.69 \pm 0.11^{*}$ & $1.51 \pm 0.16^{*}$ & $-1.07 \pm 0.19 *$ & $0.57 \pm 0.16^{*}$ & $-2.00 \pm 0.16^{*}$ & $0.21 \pm 0.14$ \\
\hline 3 & $0.22 \pm 0.14$ & $-0.00 \pm 0.23$ & $1.02 \pm 0.11^{*}$ & $0.71 \pm 0.20^{*}$ & $-1.53 \pm 0.20$ * & $-0.56 \pm 0.20 *$ & $-0.60 \pm 0.19 *$ & $-0.13 \pm 0.13$ \\
\hline 4 & $0.57 \pm 0.13 *$ & $0.52 \pm 0.20 *$ & $0.76 \pm 0.12 *$ & $0.91 \pm 0.16$ * & $0.05 \pm 0.17$ & $-0.37 \pm 0.16 *$ & $-0.15 \pm 0.14$ & $0.24 \pm 0.13$ \\
\hline 5 & $0.32 \pm 0.11 *$ & $0.79 \pm 0.18 *$ & $0.67 \pm 0.13 *$ & $-0.68 \pm 0.17$ * & $-2.07 \pm 0.18$ * & $0.14 \pm 0.18$ & $-1.80 \pm 0.17^{*}$ & $-0.21 \pm 0.12$ \\
\hline 6 & $-0.43 \pm 0.14$ * & $-0.32 \pm 0.21$ & $-0.37 \pm 0.14 *$ & $-0.51 \pm 0.22 *$ & $-1.68 \pm 0.19 *$ & $0.07 \pm 0.19$ & $-1.48 \pm 0.18 *$ & $-0.70 \pm 0.16^{*}$ \\
\hline 7 & $0.41 \pm 0.10^{*}$ & $0.27 \pm 0.27$ & $0.12 \pm 0.14$ & $-0.88 \pm 0.22 *$ & $-3.31 \pm 0.15 *$ & $1.27 \pm 0.17 *$ & $-1.94 \pm 0.14$ * & $-0.34 \pm 0.15$ * \\
\hline 8 & $0.27 \pm 0.13^{*}$ & $0.50 \pm 0.18 *$ & $0.58 \pm 0.11 *$ & $2.69 \pm 0.18 *$ & $-0.77 \pm 0.15$ * & $0.38 \pm 0.15^{*}$ & $0.41 \pm 0.14 *$ & $0.34 \pm 0.13^{*}$ \\
\hline 9 & $0.33 \pm 0.13 *$ & $0.30 \pm 0.17$ & $0.81 \pm 0.10^{*}$ & $2.73 \pm 0.16^{*}$ & $0.24 \pm 0.14$ & $0.09 \pm 0.15$ & $-0.39 \pm 0.12 *$ & $0.32 \pm 0.12 *$ \\
\hline Age (years) & & & $0.01 \pm 0.00 *$ & $-0.01 \pm 0.00 *$ & & & & \\
\hline \multicolumn{9}{|l|}{$\begin{array}{l}\text { Gender: male } \\
\text { (ref. female) }\end{array}$} \\
\hline $\begin{array}{l}\text { Other occupations } \\
\text { (ref. retired) }\end{array}$ & $-0.37 \pm 0.09 *$ & $-0.38 \pm 0.10 *$ & & & $-0.35 \pm 0.11^{*}$ & $-0.34 \pm 0.09 *$ & & $-0.41 \pm 0.08 *$ \\
\hline $\begin{array}{l}\text { Income: } 1000 \\
\text { euros/month } \\
\text { (ref. 1001) }\end{array}$ & & & & & & & $-0.24 \pm 0.10 *$ & \\
\hline $\begin{array}{l}\text { Origin: Andalusia } \\
\text { (ref. other regions) }\end{array}$ & $0.20 \pm 0.10$ & $0.59 \pm 0.17^{*}$ & $0.26 \pm 0.09 *$ & $0.37 \pm 0.16^{*}$ & $0.40 \pm 0.13 *$ & & $0.20 \pm 0.10 *$ & $0.33 \pm 0.10^{*}$ \\
\hline \multicolumn{9}{|l|}{$\begin{array}{l}\text { Travel group (ref. } \\
\text { family or others) }\end{array}$} \\
\hline Alone & & $0.39 \pm 0.16^{*}$ & & & $-0.08 \pm 0.17$ & & & \\
\hline As a couple & & $0.40 \pm 0.14 *$ & & & $0.24 \pm 0.13$ & & & \\
\hline With friends & & $0.44 \pm 0.16^{*}$ & & & $0.17 \pm 0.15$ & & & \\
\hline \multicolumn{9}{|l|}{$\begin{array}{l}\text { Accommodations } \\
\text { (ref. spa) }\end{array}$} \\
\hline $\begin{array}{l}\text { No overnight } \\
\text { stay/family or } \\
\text { friends' home }^{c}\end{array}$ & & $-0.69 \pm 0.23 *$ & & & & $-0.47 \pm 0.18^{*}$ & & $-0.39 \pm 0.14$ * \\
\hline $\begin{array}{l}\text { Apartment/chalet } \\
\text { rental unit }\end{array}$ & & $-0.24 \pm 0.24$ & & & & $-0.25 \pm 0.25$ & & $-0.20 \pm 0.19$ \\
\hline Hostel/2-star hotel & & $-0.32 \pm 0.25$ & & & & $-0.04 \pm 0.22$ & & $0.30 \pm 0.18$ \\
\hline 3- or 4-star hotel & & $-0.12 \pm 0.24$ & & & & $0.14 \pm 0.20$ & & $0.12 \pm 0.18$ \\
\hline $\begin{array}{c}\text { Number of } \\
\text { overnights stays }\end{array}$ & & & & & & & $0.03 \pm 0.01 *$ & \\
\hline $\begin{array}{l}\text { Number of previous } \\
\text { visits last } 5 \text { years }\end{array}$ & $0.04 \pm 0.02 *$ & & & & & & & \\
\hline$R^{2}$ of model & 0.114 & 0.193 & 0.248 & 0.581 & 0.474 & 0.194 & 0.419 & 0.233 \\
\hline
\end{tabular}

a: Models (one for each dimension value/total satisfaction value) using the REGRESS procedure of SUDAAN (it takes into account stratified and weighted sampling). The coefficients $\beta$ eta \pm standard error are expressed in the Table against the category "ref." [reference category). The "*" indicates significantly different category $(p<0.05)$ from the reference category. Using a "step-by-step backward" procedure based

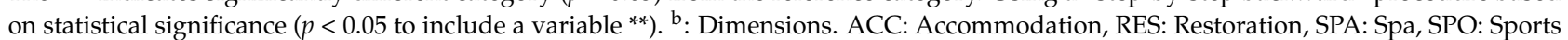
facilities, LEI: Leisure/culture/shopping, PUB: Public roads/urban and natural environment, INF: Transport infrastructures and other services. ": The coefficient of this category for the variable "Accommodation" is meaningless, since they were NS/NC values that were substituted by the mean.

\section{Discussion}

The spa tourists surveyed were, on average, 56 years old and predominantly female $(61.8 \%)$. Regarding employment status, pensioners (53.1\%) and employed individuals $(34.0 \%)$ make up a majority of the study population. Similar correlations are detected in other studies [50].

Their average monthly income is below 1000 euros $(62.9 \%)$, and they primarily come from the region of Andalusia (82.9\%). These results confirm other studies' findings [53] that spa tourism is shaped by Spain's social security subsidies and language barriers.

However, internationally, wellness tourists spend an average of 1528 per trip and 53\% more than the typical international tourist $[8,9,23]$.

Overall, this profile differs from sun and sand tourism in the summer [41], whose tourists are mostly younger, actively employed individuals from abroad, with higher incomes. However, this description does not fit winter tourism, as $40 \%$ of these tourists are retirees older than 65 years. Spa tourism also shows similarities with Mallorca's winter tourism [26] except in terms of tourists' origin, since spas visitors are primarily from within Spain and nearby areas. [50]. 
Prior research has found evidence that elderly tourists have a positive effect on seasonality, which is also an important aspect of the current demand for spa tourism [44]. About half (51.3\%) of spa tourists travel with their life partner and $83.9 \%$ choose to stay in hotels. These percentages are slightly lower than those found by studies of Mallorca [25] and sun and beach tourism on the Costa del Sol [44]. Notably, 5.8\% of the tourists who visit spa facilities do not stay overnight, which is consistent with these individuals' place of origin - in many cases, quite local. The highest percentage of overnight stays $(48.4 \%)$ is due to Imserso [54] subsidies that allow an average stay of one week [50].

The satisfaction result variable explains some factors such as age, origin, or occupation. The present results include significant differences associated with the variables of age, occupation, and income. On average, older spa users, retirees, and those with monthly incomes of less than or equal to 1000 euros are more satisfied, which matches. This could be explained by the benefits and properties of hot springs in improving health $[1-3,6,26]$ by finding lower levels of satisfaction for younger spa tourists. This may be because it is a tourist profile not focused on therapeutic treatments, as evidenced by research on Polish spa tourists [17].

The current research's results for the study population reveal that $92.4 \%$ of the people who visit spas intend to recommend them and that $63.6 \%$ express an intention to return the following year that, together with a satisfaction above the average in accommodation, restoration, or Spa, confirms that experiences connected with water correlate positively with satisfaction [7] and correlate with other investigations that have shown that when tourists visit a destination the first time, the most significant variable is the weighted average satisfaction $[42,45]$. These data show a high degree of loyalty, which indicates the possibility of long-term policies, and the need to continue to maintain quality levels services, facilities, and surroundings, or it is necessary to take care of the image, maintain loyalty, and attract new clients.

The current findings also include a significant relationship $(p<0.001)$ between future intention variables and the scores given for items in the main questionnaire with regard to greater satisfaction. Various prior studies have found a significant positive connection between perceived quality, satisfaction, and loyalty, confirming that perceived quality affects tourists' satisfaction and loyalty and that this quality is determined by satisfaction with visit variables [41]. These data correlate with the world development of tourism [8] and with the sustainable development of rural destinations [16]. In addition, results indicate that satisfaction significantly affects intention to return. Other studies have additionally shown that satisfaction is positively correlated with repeat purchase of services, loyalty, and intention to recommend to others. The present study also confirmed this association since spa tourists who plan to repeat their visit are the most satisfied with their stay in destinations, and show, as in other studies, repeated purchases of services and products [25,54].

A careful analysis of the results shown in the above tables revealed that satisfaction levels are high in all dimensions, that is, above the scale's central value of four, so the study population includes no dissatisfied users but rather more or less satisfied spa tourists which may mean that the quality of spa destinations in Andalusia is high, as argued by the literature that has studied the relationship between service quality and tourist destinations $[18,36,37,39,40]$.

The factors that show the highest average satisfaction values are 'accommodation', followed by 'spa', in third place is 'restaurants' and in fourth place with very little difference 'public roads/urban and natural environment'. Significant between dimensions, spa tourists have high satisfactions and are similar in accommodation, restaurants, spa, and public roads/urban and natural environment. For the lowest values, they are given in two groups, on the one hand, sports facilities and, on the other hand, 'transport infrastructures and other services'. It follows in this way that satisfaction is higher in the variables that depend directly on the spa. These issues correlate with those obtained in similar studies in Poland [Dryglas] and reinforce the individual motivations that demand these 
services $[19,20,24,55]$ and companies strive to seek new value propositions to attract new market segments [24].

Other researchers [56] have also confirmed high levels of satisfaction among tourists supported by the National Health Insurance Fund. The items that were given values below the current scale's average level include such variables as soft sports facilities, tennis, other sports facilities, buses, bus lines, and tourism offices. These elements correlate with other studies' conclusions [41] that, in general, tourists are more satisfied with private services than with public services.

\section{Conclusions}

Thermal spring waters have been used to address health issues since ancient times, and, currently, thousands of people travel every year to thermal spring facilities in search of healthier vacations and improved health and wellbeing. Thermal spa tourism also has a high potential for attracting varied tourist segments. Spa tourism can further be an important way to diminish seasonality, which is one of the tourism industry's main problems.

The profile of Andalusian spa tourists is predominantly female, over 56 years old, and retired with average incomes below one thousand euros.

The level of satisfaction of its users is above the average in the factors of accommodation, restaurant, spa, and public roads and natural environment and most of these clients would recommend it to others and express the intention to return which indicates Andalusians show a very high level of user loyalty.

Spain's Andalusia has thermal spas that are major tourist attractions, especially as they are located in places of great natural beauty. These facilities are an important part of the sustainable development of inland towns' economies. These research's findings thus have important implications for tourism entrepreneurs, offering new strategies to encourage diversification and providing spa hotels with solutions that attract guests interested in enhancing their health and wellbeing.

In view of the results obtained, conclusions are drawn for management, such as companies could develop strategies to attract users with younger profiles with activities, prices, or spaces more appropriate to their needs and seek the conditions to increase the satisfaction of these segments.

This study presents as a limitation that does not compromise the results the lack of a specific questionnaire for spa tourism, but the authors found it interesting that Andalusia is one of the most important sun and beach destinations in the world, and the questionnaire used was validated for that population [Otero Cordones, 2003]. A few kilometers away, this tourism coexists with the spas, and it seemed a reference that would allow comparison.

This research was carried out in the Andalusia region, which presents a limitation to the potential external validity, but it will be up to the reader to interpret whether or not these results may be applicable to their environment, depending on the possible similarities. In our opinion, it would be extrapolated to any spa in Spain or countries with similar customs and weather conditions.

Our study is a cross-sectional study, which may be a limitation that could be accompanied by qualitative studies in future research lines.

Author Contributions: Conceptualization, R.A.-A.; methodology, R.A.-A., G.G. and C.A.-A.; software, R.A.-A., G.G. and C.A.-A.; validation, R.A.-A., G.G. and C.A.-A.; formal analysis, R.A.-A., G.G. and C.A.-A.; investigation, R.A.-A., G.G. and C.A.-A.; resources, R.A.-A., G.G. and C.A.-A.; data curation, R.A.-A., G.G. and C.A.-A.; writing-original draft preparation, R.A.-A., G.G. and C.A.-A.; writing-review and editing, R.A.-A., G.G. and C.A.-A.; visualization, R.A.-A., G.G. and C.A.-A.; supervision, R.A.-A., G.G. and C.A.-A.; project administration, R.A.-A., G.G. and C.A.-A. All authors have read and agreed to the published version of the manuscript.

Funding: This research received no external funding.

Institutional Review Board Statement: Not applicable.

Informed Consent Statement: Not applicable. 
Data Availability Statement: The data presented in this study are available on request from the corresponding author.

Acknowledgments: The authors would like to thank the professionals and experts of the Andalusian spa sector for their participation in this research project.

Conflicts of Interest: The authors declare no conflict of interest.

\section{References}

1. Valenzuela, M.A. Cura balnearia, medio ambiente, turismo. Estud Turísticos 1984, 84, 39-48.

2. De la Hoz-Correa, A.; Muñoz-Leiva, F.; Bakucz, M. Past themes and future trends in medical tourism research: A co-word analysis. Tour. Manag. 2018, 65, 200-211. [CrossRef]

3. Pérez, C.P.G.; Soutelo, S.G.; Mosqueira, M.L.M.; Soto, J.L.L. Spa techniques and technologies: From the past to the present. Sustain. Water Resour. Manag. 2019, 5, 71-81. [CrossRef]

4. Smith, M.; Puczkó, L. More than a special interest: Defining and determining the demand for health tourism. Tour. Recreat. Res. 2015, 40, 205-219. [CrossRef]

5. Gustavo, N.S. A 21st-century approach to health tourism spas: The case of Portugal. J. Hosp. Tour. Manag. 2010, 17, 127-135. [CrossRef]

6. Koskinen, V.; Wilska, T.-A. Identifying and understanding spa tourists' wellness attitudes. Scand. J. Hosp. Tour. 2019, 19, 259-277. [CrossRef]

7. Campón-Cerro, A.M.; Di-Clemente, E.; Hernández-Mogollón, J.M.; Folgado-Fernández, J.A. Healthy water-based tourism experiences: Their contribution to quality of life, satisfaction and loyalty. Int. J. Environ. Res. Public. Health 2020, 17, 1961. [CrossRef]

8. Global Wellness Institute. 2020. Available online: https://globalwellnessinstitute.org/ (accessed on 24 January 2021).

9. Szromek, A.R.; Wybrańczyk, K. Proposal of Value for Customer of Spas: Expectations of Spa Patients and Tourist in Polish Spas. Sustainability 2019, 11, 3598. [CrossRef]

10. Pelegrín-Borondo, J.; Araújo-Vila, N.; Fraiz-Brea, J.A. Comparison of Spa Choice between Wellness Tourists and Healthcare/Medical Tourists. Healthcare 2020, 8, 544. [CrossRef]

11. World Medical Association. WMA Statement on Health Promotion-WMA-The World Medical Association. 2020. Available online: https: / /www.wma.net/policies-post/wma-statement-on-medical-tourism/ (accessed on 17 March 2020).

12. World Tourism Organization and European Travel Commission. Exploring Health Tourism—Executive Summary. 2018. Available online: https: / /www.e-unwto.org/doi/book/10.18111/9789284420308 (accessed on 24 January 2021). [CrossRef]

13. UNWTO. The Impact of Covid 19 on International Tourism 2020. Available online: https:/ / webunwto.s3.eu-west-1.amazonaws. com/s3fs-public/2020-09/TMIC.pdf (accessed on 17 September 2020).

14. Lopes Brenner, E. La motivación turística: El caso de la región de las aguas termales de Goiás, Brasil. Boletín Asoc. Geógr. Españoles 2006, 42, 303-316.

15. Boletín Oficial del Estado. Ley 22/1973, de 21 de julio, de Minas. BOE Boletín Oficial Estado 1973, 1-24. Available online: https: / / www.boe.es/buscar/act.php?id=BOE-A-1973-1018 (accessed on 24 January 2021).

16. Medina-Muñoz, D.R.; Medina-Muñoz, R.D. Critical issues in health and wellness tourism: An exploratory study of visitors to wellness centres on Gran Canaria. Curr. Issues Tour. 2013, 16, 415-435. [CrossRef]

17. Dryglas, D.; Salamaga, M. Segmentation by push motives in health tourism destinations: A case study of Polish spa resorts. J. Destin. Mark. Manag. 2018, 9, 234-246. [CrossRef]

18. Adongo, C.A.; Amuquandoh, F.E.; Amenumey, E.K. Modelling spa-goers' choices of therapeutic activities. J. Hosp. Tour. Manag. 2017, 1, 105-113. [CrossRef]

19. Yeoman, I. Tomorrow's Tourist: Scenarios and Trends, 1st ed.; Routledge: Oxford, UK, 2008; p. 357.

20. Clark-Kennedy, J.; Cohen, M. Indulgence or therapy? Exploring the characteristics, motivations and experiences of hot springs bathers in Victoria, Australia. Asia Pac. J. Tour. Res. 2017, 22, 501-511. [CrossRef]

21. Loureiro, S.M.C.; Almeida, M.; Rita, P. The effect of atmospheric cues and involvement on pleasure and relaxation: The spa hotel context. Int. J. Hosp. Manag. 2013, 35, 35-43. [CrossRef]

22. Chrobak, A.; Ugolini, F.; Pearlmutter, D.; Raschi, A. Thermal tourism and geoheritage: Examining visitor motivations and perceptions. Resources 2020, 9, 58. [CrossRef]

23. Szromek, A.R.; Naramski, M. A business model in spa tourism enterprises: Case study from Poland. Sustainability 2019, 11, 2880. [CrossRef]

24. Han, H.; Kiatkawsin, K.; Kim, W.; Lee, S. Investigating customer loyalty formation for wellness spa: Individualism vs. collectivism. Int. J. Hosp. Manag. 2017, 67, 11-23. [CrossRef]

25. Baloglu, S.; Busser, J.; Cain, L. Impact of experience on emotional well-being and loyalty. J. Hosp. Mark. Manag. 2019, 28, 427-445. [CrossRef]

26. Kozak, M.; Rimmington, M. Tourist satisfaction with Mallorca, Spain, as an off-season holiday destination. J. Travel Res. 2000, 38, 260-269. [CrossRef]

27. Joppe, M. One country's transformation to spa destination: The case of Canada. J. Hosp. Tour. Manag. 2010, 17, 117-126. [CrossRef] 
28. Soler, I.P.; Gemar, G.; Correia, M.B. The climate index-length of stay nexus. J. Sustain. Tour. 2020, 28, 1272-1289. [CrossRef]

29. Assaf, A.G.; Josiassen, A.; Agbola, F.W. Attracting international hotels: Locational factors that matter most. Tour. Manag. 2015, 47, 329-340. [CrossRef]

30. Rigall-I-Torrent, R.; Fluvià, M.; Ballester, R.; Saló, A.; Ariza, E.; Espinet, J.M. The effects of beach characteristics and location with respect to hotel prices. Tour. Manag. 2011, 32, 1150-1158. [CrossRef]

31. Yang, Y.; Luo, H.; Law, R. Theoretical, empirical, and operational models in hotel location research. Int. J. Hosp. Manag. 2014, 36, 209-220. [CrossRef]

32. Juan, P.J.; Lin, S.Y. Selecting resort locations. Tour Econ. 2013, 19, 1249-1272. [CrossRef]

33. Gemar, G.; Soler, I.P.; Guzman-Parra, V.F. Predicting bankruptcy in resort hotels: A survival analysis. Int. J. Contemp. Hosp. Manag. 2019, 31, 1546-1566. [CrossRef]

34. Gémar, G.; Moniche, L.; Morales, A.J. Survival analysis of the Spanish hotel industry. Tour. Manag. 2016, 54, 428-438. [CrossRef]

35. Lado-Sestayo, R.; Vivel-Búa, M.; Otero-González, L. Survival in the lodging sector: An analysis at the firm and location levels. Int. J. Hosp. Manag. 2016, 59, 19-30. [CrossRef]

36. Soler, I.P.; Gemar, G. A measure of tourist experience quality: The case of inland tourism in Malaga. Total. Qual. Manag. Bus. Excell. 2017, 30, 1466-1479. [CrossRef]

37. Chen, C.M.; Chen, S.H.; Lee, H.T.; Tsai, T.H. Exploring destination resources and competitiveness-A comparative analysis of tourists' perceptions and satisfaction toward an island of Taiwan. Ocean Coast Manag. 2016, 119, 58-67. [CrossRef]

38. Nam, J.H.; Lee, T.J. Foreign travelers' satisfaction with traditional Korean restaurants. Int. J. Hosp. Manag. 2011, 30, 982-989. [CrossRef]

39. Albayrak, T.; Caber, M.; Öz, E.K. Assessing Recreational Activities' Service Quality in Hotels: An Examination of Animation and Spa and Wellness Services. J. Qual. Assur. Hosp. Tour. 2017, 18, 218-234. [CrossRef]

40. Cong, L.C. A formative model of the relationship between destination quality, tourist satisfaction and intentional loyalty: An empirical test in Vietnam. J. Hosp. Tour. Manag. 2016, 26, 50-62. [CrossRef]

41. Cordones, C.O. Evaluación de la calidad de destinos turísticos de sol y playa: Una aplicación a la Costa del Sol. Universidad de Málaga. 2003. Available online: http:/ /www.biblioteca.uma.es/bbldoc/tesisuma/16699336.pdf (accessed on 18 July 2020).

42. Ahani, A.; Nilashi, M.; Ibrahim, O.; Sanzogni, L.; Weaven, S. Market segmentation and travel choice prediction in Spa hotels through TripAdvisor's online reviews. Int. J. Hosp. Manag. 2019, 80, 52-77. [CrossRef]

43. Kucukusta, D.; Guillet, B.D. Lifestyle Segmentation of Spa Users: A Study of Inbound Travelers to Hong Kong. Asia Pac. J. Tour. Res. 2016, 21, 239-258. [CrossRef]

44. Kamata, H.; Misui, Y. Why do they choose a spa destination? The case of Japanese tourists. Tour. Econ. 2015, 21, 283-305. [CrossRef]

45. Kucukusta, D.; Guillet, B.D. Measuring spa-goers' preferences: A conjoint analysis approach. Int. J. Hosp. Manag. 2014, 41, 115-124. [CrossRef]

46. González, M.E.A.; Comesaña, L.R.; Brea, J.A.F. Assessing tourist behavioral intentions through perceived service quality and customer satisfaction. J. Bus. Res. 2007, 60, 153-160. [CrossRef]

47. Escriche, M.M. Ocio y turismo en la Región de Murcia: Alternativas para su diversificación. Cuad. Tur. 2004, 14, 113-177.

48. Joukes, V.; Gerry, C. Website effectiveness in wellness promotion by Portuguese spas. J. Hosp. Tour. Manag. 2010, 17, 136-143. [CrossRef]

49. Esiyok, B.; Kurtulmuşoğlu, F.B.; Özdemir, A. Heterogeneity in the determinants of length of stay across middle age and senior age groups in thermal tourism. J. Travel Tour. Mark. 2018, 35, 531-540. [CrossRef]

50. Consejería de Turismo y Comercio de Andalucía. Turismo de salud y bienestar. 2015. Available online: https://www. juntadeandalucia.es/turismoydeporte/opencms/areas/servicios/centro-documentacion/publicaciones/turismo/Turismode-salud-y-bienestar-en-Andalucia-00001/ (accessed on 31 January 2021).

51. Alonso, J.; Arboleda, A.M.; Rivera-Triviño, A.F.; Mora, D.Y.; Tarazona, R.; Ordoñez-Morales, P.J. Técnicas de investigación cualitativa de mercados aplicadas al consumidor de fruta en fresco. Estud. Gerenciales 2017, 33, 412-420. [CrossRef]

52. Esteban, I.; Fernández, E. Fundamentos y Técnicas de Investigación Comercial.; ESIC editorial: Madrid, Spain, 2017.

53. Landis, J.R.; Koch, G.G. The Measurement of Observer Agreement for Categorical Data. Biometrics 1977, 33, 159-174. [CrossRef] [PubMed]

54. Kapczyński, A.; Szromek, A.R. Hypotheses concerning the development of Polish spas in the years 1949-2006. Tour. Manag. 2008, 29, 1035-1037. [CrossRef]

55. Berman, B. How to delight your customers. Calif. Manag. Rev. 2005, 48, 129-151. [CrossRef]

56. Loke, Z.; Kovács, E.; Bacsi, Z. Assessment of service quality and consumer satisfaction in a Hungarian spa. Deturope Cent. Eur. J. Reg. Dev. Tour 2018, 10, 124-146. 